\title{
Protein Arginine N-Methyltransferase 5
}

National Cancer Institute

\section{Source}

National Cancer Institute. Protein Arginine N-Methyltransferase 5. NCI Thesaurus. Code C127857.

Protein arginine $\mathrm{N}$-methyltransferase 5 (637 aa, $\sim 73 \mathrm{kDa}$ ) is encoded by the human PRMT 5 gene. This protein is involved in the methylation of arginine. 